\title{
KONSEP NILAI WAKTU DARI UANG DALAM SUDUT PANDANG EKONOMI ISLAM
}

\author{
Rahma Ulfa Maghfiroh \\ UIN Sunan Ampel Surabaya \\ rahma.ulfa@uinsby.ac.id
}

\begin{abstract}
Abstrak
Kemajuan pemikiran dan peradaban manusia terus berkembang, begitu pula dengan perkembangan ekonomi yang semakin pesat. Perkembangan teori keuangan yang saat ini juga bermunculan sehingga menjadi masalah yang hangat diperdebatkan, salah satunya adalah konsep time value of money atau lebih dikenal dengan nilai waktu dari uang. Konsep nilai waktu dari uang ini menyebutkan bahwa nilai uang saat ini lebih berharga dari sejumlah nilai uang yang sama di masa mendatang. Agar uang tidak tergerus nilainya seiring dengan berjalannya waktu maka hal tersebut tidak terlepas dari yang namanya bunga. Menurut konsep ekonomi Islam menegaskan bahwa dalam al-Quran telah mengharamkan bunga atas uang, di mana hal tersebut disamakan dengan riba. Dalam berbagai pandangan yang dikaji dari sudut pandang Islam teori nilai waktu dari uang bertentangan dengan prinsip ekonomi Islam. Dalam ekonomi Islam, uang bukanlah modal serta tidak memberikan kegunaan, namun fungsi uang tersebut yang memberikan kegunaan. Dalam Islam memandang time value of money yang populer dengan nilai waktu uang kemudian digantikan dengan konsep economic value of time. Konsep tersebut menunjukkan bukan uang yang memiliki waktu, namun waktulah yang memiliki nilai ekonomis. Maka dalam tulisan ini, penulis akan mencoba menjawab bagaimana konsep nilai waktu dari uang dalam sudut pandang ekonomi Islam?, dengan metode kualitatif dan pendekatan library research didapat bahwa dalam ekomoni Islam tidak mengenal nilai waktu uang atau time value of money namun teori economic value of time lah yang dianggap benar dari pandangan ekonomi Islam. Artinya uang itu sendiri sebenarnya tidak memiliki nilai waktu, namun waktulah yang memiliki nilai ekonomis.
\end{abstract}

Kata kunci : waktu, uang, nilai ekonomi, ekonomi Islam

\section{PENDAHULUAN}

Pada era saat ini perekonomian semakin berkembang karena adanya perluasan pasar yang mendorong peningkatan produktivitas. Perdagangan baik nasional maupun internasional terus berkembang yang mendorong sistem perekonomian beralih dari sistem perekonomian yang bersifat primitif menjadi sistem perekonomian yang lebih modern, efektif dan efisien. Dibutuhkan alat tukar untuk dapat memudahkan transaksi karena kompleksnya 
perdagangan yang berkembang saat ini. Uang dapat dijadikan sebagai alat untuk mempermudah terjadinya transaksi, dengan menjadikannya sebagai alat pertukaran barang dan jasa dalam suatu wilayah. $^{1}$

Dalam ilmu ekonomi konvensional menyebutkan uang memiliki nilai waktu, menegaskan bahwa uang pada masa sekarang memiliki nilai yang jumlahnya berbeda dengan jumlah uang pada masa depan. Artinya, sejumlah uang yang dimiliki seseorang pada hari ini nilainya tidak akan sama dengan satu tahun yang akan datang. Karena waktu terus berjalan, maka ada kebutuhan untuk meningkatkan nilai nominal uang agar nilai riil dari uang tetap sama. Maka muncullah konsep uang harus selalu bertambah dan bertambah karena adanya waktu yang berjalan. Oleh karena itu, konsep tersebut sangat terkait dengan konsep diskonto. Pada positive time preference Diskonto biasanya berdasarkan pada besaran tingkat bunga (interest rate), sehingga bunga berfungsi sebagai alat ukur dalam menentukan nilai waktu modal dan investasi. $^{2}$

Berbeda dengan konsep dalam ekonomi Islam. Time value of money

1 Kasmir, Bank dan lembaga keuangan lainnya.ed.revisi, (Jakarta : Rajawali Pers.2008), h.52

${ }^{2}$ Iggi H. Achsien, Investasi Syariah di Pasar Modal: Menggagas Konsep danPraktik Manajemen Portofolio Syariah (Jakarta: Gramedia Pustaka Utama, 2003),hlm. 45 atau banyak dikenal dengan nilai waktu dari uang dianggap riba oleh sebagian besar ahli ekonomi Islam sehingga konsep tersebut diharamkan. ${ }^{3}$ Dalam ekonomi Islam, uang merupakan alat penukar yang memiliki nilai namun tidak bisa diposisikan sebagai barang dagangan. Uang akan bermanfaat jika menjadi alat tukar untuk memperoleh benda yang nyata atau untuk membeli jasa. Sehingga uang tersebut tidak dapat diperjual belikan. Berdasarkan dari uraian tersebut, Bagaimana konsep nilai waktu dari uang dalam sudut pandang ekonomi Islam? Hal inilah permasalahan yang akan dibahas menjadi pada tulisan ini.

\section{KONSEP UANG}

Pada awal peradapan, manusia dapat memenuhi kebutuhannya sendiri dengan cara berburu atau memakan buah buahan. Namun seiring berjalannnya waktu populasi manusia semakin bertambah. Guna memenuhi kebutuhan mereka yang lebih meningkat maka muncullah sistem barter. Barter merupakan awal dari bentuk perdagangan, namun pada prakteknya pada sistem barter ini muncul banyak kendala pada saat bertransaksi. Salah

\footnotetext{
3 Agar tidak terkena unsur riba maka ada beberapa syarat yang ditentukan oleh ulama fikih, lebih jauhnya silahkan lihat Bakhrul Huda, "Etika Pertukaran Valas Dalam Pasar Valuta Asing Perspektif Fikih Sarf" dalam Iqtishadia Jurnal Ekonomi dan Perbankan Syariah Vol. 5 No. 1 (Juni 2018), 12-18
} 
satunya adalah sulitnya menemukan orang yang mau menukar barang yang kita butuhkan, selain itu tidak ada alat ukur yang pasti untuk menilai apakah barter yang dilaksanakan tersebut sudah sesuai.

$$
\text { Karena adanya berbagai }
$$

kesulitan yang ditemukan pada sistem barter maka manusia berusaha mencari suatu benda yang dapat digunakan untuk menjadi alat ukur secara pasti pada benda yang akan diperjual belikan tersebut. Maka muncullah konsep uang sebagai alat ukur dalam kegiatan jual beli.

Definisi tentang uang dapat kita lihat pada buku-buku ekonomi. Beberapa ahli mendefinisikan uang sebgai berikut :

a. Dalam kamus besar bahasa Indonesia uang merupakan alat penukaran atau standar pengukur nilai yang dikeluarkan oleh pemerintah suatu Negara berupa kertas, emas, perak atau logam lain yang dicetak dengan bentuk dan gambar tertentu.

b. Kasmir mendefinisikan uang secara luas sebagai sesuatu yang dapat diterima secara umum sebagai alat pembayaran dalam suatu wilayah tertentu atau sebagai alat untuk pembelian barang dan jasa.

c. Muhammad mendefinisikan uang adalah benda yang dijadikan sebagai ukuran dan penyimpan nilai semua barang. d. Sedangkan menurut fiqh Islam uang biasa disebut sebagai nuqud atau

tsaman. Secara umum, uang dalam Islam adalah alat tukar atau transaksi dan pengukur nilai barang dan jasa untuk memperlancar transaksi perekonomian. ${ }^{4}$

Maka dapat disimpulkan bahwa uang adalah standart yang digunakan sebagai alat tukar terhadap barang dan jasa untuk memenuhi berbagai kebutuhan manusia, dengan ketentuan alat tukar tersebut dapat diterima pada daerah tertentu.

\section{FUNGSI UANG}

Uang berperan penting dalam kehidupan sehari hari untuk menjalankan fungsi perekonomian. Secara umum dapat kita lihat fungsi-fungsi dari uang adalah sebagai berikut :

a. Alat yang berfungsi untuk tukar menukar (medium of change)

b. Alat yang digunakan sebagai satuan hitung (unit of account)

c. Penyimpan kekayaan (store of value)

d. Alat pembayaran tunda (different payment)

Dari fungsi diatas ternyata ada yang berbeda antara sistem kapitalis dan sistem Islam dalam memandang dan memperlakukan uang. Pada

\footnotetext{
${ }^{4}$ Andri Soemitra, Bank dan Lembaga Keuangan Syariah, (Jakarta:Kencana, 2009), hlm. 3
} 
perekonomian kapitalis uang mempunyai fungsi lain sebagai alat tukar yang sah, yaitu mempunyai fungsi sebagai komoditas, maka uang dapat diperjualkan belikan, bahkan uang juga bisa disewakan.

Namun menurut pandangan Islam segala sesuatu yang berfungsi sebagai uang, maka hanya berfungsi sebagai alat tukar. Uang bukanlah komoditas yang dapat diperjual belikan. Islam mengajarkan agar uang hanya berfungsi sebagai alat tukar saja. Karena semakin banyak uang yang beredar di pasar maka akan semakin akan semakin banyak pula barang dan jasa yang diproduksi dan diserap oleh pasar. Akibatnya pertumbuhan ekonomi akan semakin meningkat, tanpa ada kekhawatiran terjadinya collaps seperti pertumbuhan ekonomi dalam sistem kapitalis ${ }^{5}$.

\section{PENGERTIAN DAN KONSEP NILAI WAKTU DARI UANG}

Dalam bidang ekonomi kita mengenal konsep nilai waktu uang. Definisi yang sering digunakan pada ekonomi konvensional dalam menjeaskan nilai waktu uang adalah " $A$ dollar today is worth more than a dollar in the future because a dollar today can

${ }^{5}$ Emily Nur Saidy, S.E., M.E "UANG DALAM TINJAUAN EKONOMI ISLAM" LAA MAISYIR, Volume 6, Nomor 2, (2017), h. 25-40 be invested to get a return". ${ }^{6}$ Pengertian tersebut menjelaskan sejumlah nilai uang yang dimiliki saat ini selalu memiliki nilai yang lebih berharga dengan uang yang dimiliki pada saat yang akan datang, karena uang yang diterima pada saat ini akan dapat diinvestasikan untuk memperoleh hasil yang lebih besar dimasa yang akan datang, dapat disimpulkan adanya perbedaan nilai uang saat ini dengan nilai uang di masa depan yang terjadi karena adanya unsur waktu. Faktor yang menghubungkan nilai waktu adalah tingkat diskonto yang diproksi dengan tingkat bunga. Konsep ini dikembangkan dari berbagai teori bunga (theory of interest), dari beberapa pendapat para ekonom kapitalis. Kita dapat menemukan tokoh terkenal dalam classical theory of interest yaitu Adam Smith dan David Ricardo, yang mengeluarkan pendapat bahwa bunga mencerminkan kompensasi yang diperoleh si pemberi ( lender) oleh si peminjam (borrower) sebagai balas jasa atas profit yang didapatkan dari uang yang dipinjamkan pada periode tertentu.

Terdapat beberapa alasan yang mendasari munculnya konsep nilai waktu uang, yaitu: ${ }^{7}$

1. Presence of inflation, dengancara memasukan tingkat inflasi dalam perekonomian. Alasan tersebut

\footnotetext{
${ }^{6}$ M.Nur Rianto Al Arif, Teori Makroekonomi Islam : Konsep,Teori, dan Analisis,(Bandung, Alfabeta,2010), 62

7 Agus Sartono, Manajemen Keuangan,(Yogyakarta: BPFE, 1997), 65-70
} 
dapat dipahami dengan contoh sebagai berikut; apabila tingkat inflasi di suatu negara $10 \%$ pert ahun. Seseorang dapat membeli $10 \mathrm{~kg}$ beras pada saat ini dengan membayar Rp 10.000, apabila orang tersebut membelinya pada tahun depan dengan sejumlah uang yang nilai nya sama $\mathrm{Rp}$ 10.000 ia hanya dapat membeli $9 \mathrm{~kg}$ beras. Berkurangnya daya beli sejumlah uang tersebut terjadi sebagai akibat dari inflasi.

2. Preference present consumption to future consumption, bagi kebanyakan individu, present consumption lebih disukai dari pada future consumptio. Setiap individu pada umumnya akan lebih menyukai dan memilih kegiatan konsumsi saat ini juga bila dibandingkan dengan melakukan kegiatan konsumsi di masa mendatang. Dapat diilustrasikan bahwa jika diasumsikan tidak ada tingkat inflasi sekalipun, dengan uang Rp10.000 seseorang tetap bisa membeli 10 buah roti pada saat ini maupun pada tahun depan. Namun bagi sebagian besar orang, kegiatan konsumsi 10 buah roti lebih disukai dilakukan sekarang dari pada dilakukan pada tahun. Pada kerangka pikir ini, meskipun tidak terdapat tingkat inflasi pada suatu struktur perekonomian setiap orang lebih suka Rp 10.000 saat ini untuk dibelanjakan pada kegiatan konsumsi. Maka perlu kompensasi atas tertundnya konsumsi pada masa yang akan datang, meskipun jumlah nya sama

Seorang manajer keuangan memerlukan konsep nilai waktu uang untuk mengambil keputusan pada saat melakukan investasi di suatu aktiva dan pengambilan keputusan penting pada saat menetukan sumber dana pinjaman yang akan dipilih.

Nilai waktu dari uang dapat dijelaskan dengan beberapa konsep, yaitu: ${ }^{8}$

Nilai akan datang (future value)

Future Value merupakan nilai uang di masa yang akan datang dari sejumlah uang tertentu yang dimiliki sekarang. Nilai future value dapat dihitung dengan cara berikut ;

$\mathrm{FV}_{\mathrm{r}, \mathrm{n}}=\mathrm{P}_{0}(1+\mathrm{r})^{\mathrm{n}}$

Diman $\mathrm{FV}_{\mathrm{r}, \mathrm{n}}=$ future value di tahun $\mathrm{n}$ dengan tingkat bunga $r$

$$
\begin{aligned}
& \mathrm{P} 0=\text { investasi awal } \\
& \mathrm{r}=\text { nilai suku bunga } \\
& \mathrm{n} \quad=\text { tahun ke } \mathrm{n} \text { (jumlah }
\end{aligned}
$$

periode/tahun), contohnya apabila seseorang yang punya uang Rp. 1.000.000, dia menyimpan uang tersebut dengan menabung di bank dengan tingkat bunga $10 \%$ pertahun, Berapa

8 I made Sudana, Manajemen Keuangan, (Jakarta, Airlangga, 2017), h.85 
jumlah tabungan orang tersebut setelah 5 tahun kemudian?

Dari contoh soal tersebut dapat kita lihat

$\begin{aligned} \text { FV } & =\mathrm{P}_{0}(1+\mathrm{r})^{\mathrm{n}} \\ \text { Maka FV } & =1.000 .000(1+0,1)^{5} \\ \text { Nilai FV } & =\text { Rp. } 1.610 .510\end{aligned}$

Nilai Sekarang (Present Value)

Konsep Present value merupakan kebalikan dari future value, yaitu nilai sekarang dari sejumlah uang tertentu yang akan di terima di masa datang. Nilai present value dapat dihitung dengan cara berikut :

$\mathrm{FV}_{\mathrm{r}, \mathrm{n}}=\mathrm{P}_{0}(1+\mathrm{r})^{\mathrm{n}}$

Present value $=\mathrm{P}_{0}$

$\mathrm{P}_{0}=\mathrm{FV}^{\mathrm{r}, \mathrm{n}}(1+\mathrm{r})^{-\mathrm{n}}$

Dapat dilihat contoh, suatu investor menawarkan sebuah alternatif penerimaan pembayaran uang sejumlah Rp. 1.610,50 pada akhir tahun kelima apabila suku bunga $10 \%$ pertahun, maka nilai dasar untuk menerima atau menolak tawaran alternatif adalah sebesar Rp1.000

Nilai Rp.1000 tersebut diperoleh dengan perhitungan berikut ;

$$
\begin{aligned}
& \mathrm{FVr}, \mathrm{n}=\mathrm{P}_{0}(1+\mathrm{r})^{\mathrm{n}} \\
& \begin{aligned}
\mathrm{P} 0= & \underline{\mathrm{FVr}, \mathrm{n}} \\
& (1+\mathrm{r})^{\mathrm{n}} \\
= & \mathrm{FVr}, \mathrm{n}\left[(1+\mathrm{r})^{-\mathrm{n}}\right] \\
= & \mathrm{FV} 10 \%, 5 \text { th }\left[(1+0,1)^{-5}\right] \\
= & \operatorname{Rp~} 1.610,5(0,6209) \\
= & \operatorname{Rp} 1.000
\end{aligned}
\end{aligned}
$$

Konsep nilai waktu uang berkaitan dengan analisis modal dan investasi, maka sudah lazim bila time value of money disajikan bersama cost of capital, karena bila membahas modal dan investasi tidak bisa terlepas dari konsep disconto. Menurut Iggi, konsep diskonto tidak bisa terlepas dalam analisis (capical bugeting) teori modal dan investasi. Dalam prakteknya digunakan dalam mengevaluasi suatu proyek atau pun keputusan invesatasi, misalnya pada penentuan net present value (NPV), cost benefi analysis, internal required rate of return (IRR), deviden model dalam asset valuation, dan seterusnya. Tingkat Diskonto inilah yang dimaksud dengan Time Value of Money atau nilai nilai waktu uang. ${ }^{9}$

\section{PANDANGAN EKONOMI ISLAM TENTANG NILAI WAKTU DARI UANG}

Membahas persoalan riba sebetulnya tidak bisa terlepas dengan masalah uang. Berbeda pandangan dengan teori ekonomi konvensional (kapitalisme), Islam memposisikan uang sebagai sarana alat tukar dan penyimpan nilai, tetapi uang tidak bisa dijadikan barang dagangan. Uang menjadi berguna hanya jika ditukar dengan benda yang nyata atau jika digunakan untuk membeli jasa. ${ }^{10}$

\footnotetext{
${ }^{9}$ Iggi H. Achsien, Investasi Syariah di Pasar Modal: Menggagas Konsep danPraktik Manajemen Portofolio Syariah (Jakarta: Gramedia Pustaka Utama, 2003),hlm. 45

${ }^{10}$ Rahmat Ilyas: "Time Value of Money dalam Perspektif Hukum Islam” AL-'ADALAH Vol. 14, Nomor 1(2017)
} 
Dalam kajian teori ekonomi konvensional, nilai waktu uang didefiisikan sebagai " $A$ dollar today is worth more than a dollar in the future because a dollar today can be invested to get a return. Menurut Adiwarman Karim definisi tersebut tidak akurat, karena setiap investasi tidak hanya mempunyai kemungkinan positif namun juga selalu mempunyai kemungkinan untuk mendapatkan positif, negative atau no return.

Islam memposisikan uang sebagai flow concept. Artinya, dalam perekonomian uang harus digunakan dan diputar kembali dan tidak boleh dibiarkan saja tidak digunakan pada beberapa jangka waktu yang terlalu lama, apalagi sampai tahunan. Dalam ekonomi Islam konsep time value of money tidak sesuai dengan Islam, karena nilai waktu uang ini menambah nilai kepada uang hanya didasarkan bertambahnya waktu namun bukan melalui usaha

Dalam ekomoni Islam tidak dikenal dengan adanya time value of money, namun lebih mengenalkan konsep economic value of time. Pendapat tersebut didukung oleh beberapa alasan. Salah satunya disebutkan bahwa Teori time value of time merupakankekeliruan karena mengadopsi dari konsep ilmu pertumbuhan populasi dan tidak ditemukan pada ilmu fiance.
Dalam menghitung pertumbuhan populasi digunakan rumus:

$\mathrm{Pt}=\mathrm{Po}(1+\mathrm{r})$

Rumus tersebut langsung diadopsi ke dalam ilmu finance menjadi teori bunga majemuk:

$\mathrm{FV}=\mathrm{PV}(1+\mathrm{r})$

Maka, future value dari nilai uang disamakan dengan besarnya jumlah populasi tahun ke-n, present value dari nilai uang disamakan dengan besarnya populasi pada tahunke-0, sedangkan tingkat pertumbuhan populasi disamakan dengan tingkat suku bunga. Hal inilah yang memnjadi kekeliruan, karena uang tidak sebagai makhluk hidup yang dapat tumbuh dan berkembang dengan sendirinya. ${ }^{11}$

Pada praktik ekonomi konvensional, uang dianggap sama dengan sel, sehingga uang dianggap hidup dan dapat berkembang dalam hitungan waktu. Konsep nilai waktu uang ini yang akhirnya mampu menjadi alasan paling rasional untuk bisa menerima atau bahkan mengharuskan adanya bunga uang. Namun hal tersebut bertentangan dengan konsep Islam yang dengan tegas menolak adanya bunga karena bunga masuk dalam kategori praktik riba.

Konsep nilai waktu uang tidak sesuai dengan syariat Islam dan tidak dapat diterapkan dalam ekonomi Islam, karena konsep nilai waktu uang tidak bisa terlepas dari bunga. Sejalan dengan

\footnotetext{
11 Adiwarman A Karim, Ekonomi Makro Islami, (Jakarta:PT.Rajagrafindo Persada. 2010)h. 88
} 
pendapat para ulama yang sepakat bahwa posisi bunga sama dengan riba (haram). Hal tersebut berdasarkan pada firman Allah swt. dalam QS. al-Baqarah ayat 278:

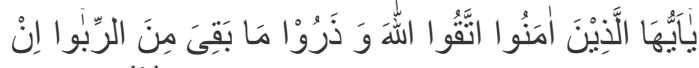

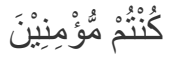

"Hai orang-orang yang beriman, bertakwalah kepada Allah dan tinggalkan sisa Riba (yang belum dipungut) jika kamu orang-orang yang beriman." (QS. al-Baqarah [2]: 278)

Kita semua sepakat bahwa setiap orang mendapatkan jatah waktu yang sama setiap harinya 24 jam. Bagi semua orang waktu memiliki kuantitas yang sama, yaitu 24 jam dalam sehari, dan 7 hari dalam seminggu. Namun, nilai waktu berbeda kualitasnya antara satu orang dengan yang orang yang lainnya, tergantung bagaimana seseorang mampu menggunakan nilai waktu tersebut dengan maksimal. Jadi, faktor yang menentukan nilai waktu adalah bagaimana seseorang itu mampu memanfaatkan waktu dengan sebaikbaiknya.

Nilai waktu disebutkan dalam Al-Quran, pembahasan juga yang menentukan niali ekonomi waktu tergantung oleh amal baik, keimanan, dan agar saling mengingatkan pada hal kebaikan dan kesabaran.

Disebutkan dalam surat Al-ashr ayat 1-3

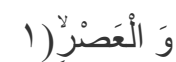

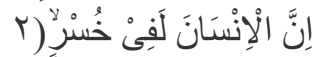

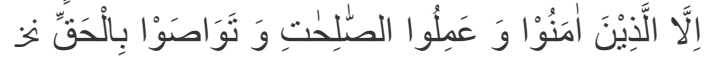

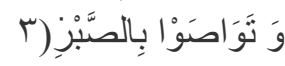

"Demi masa. Sesungguhnya manusia itu benar-benar dalam kerugian, kecuali orang-orang yang beriman dan mengerjakan amal saleh dan nasehat menasehati supaya mentaati kebenaran dan nasehat menasehati supaya menetapi kesabaran"12

Waktu adalah modal utama manusia, apabila waktu tidak digunakan untuk melakukan hal yang positif, waktu akan pergi begitu saja. Hilang tidak mendapat apa-apa,jangankan keuntungan yang diperoleh, modal waktu pun akan hilang begitu saja. Sayyidina Ali r.a. pernah berkata: "rezeki yang tidak diperoleh hari ini masih dapat diharapkan lebih dari itu diperoleh besok, tetapi waktu yang berlalu hari ini tidak mungkin dapat diharapkan kembali esok."13

Ditinjau dari sudut ekonomi, dapat disimpulkan bahwa keuntungan dapat diperoleh setelah melakukan transaksi bisnis. Jadi seseorang yang melakukan yang melakukan aktivitas dan transaksi bisnis secara efektif akan memperoleh keuntungan.

Konsep economic value of time ditawarkan sebagai solusi dari nilai

12 Departemen Agama, Alquran dan Terjemahnya (Semarang: Asy-Syifa, 2000), h. 432.

${ }^{13}$ M. Quraish Shihab, Tafsir al-Misbah, 15, Cet. 5 (Jakarta: Lentera Hati, 2012), h. 585. 
waktu, bukan uang yang mempunyai nilai waktu, namun waktulah yang bernilai ekonomis. Ekonomi Islam memberikan solusi agar sejumlah uang yang kita miliki saat ini ketika di masa mendatangtidak mengalami penurunan( jika didiamkan akn tergerus inflasi) atau memiliki nilai tetap yang tinggi tetap memiliki nilai tinggi,yaitu: Pertama, melakukan investasi, menabung, serta dengan bisnis dengan prinsip sistem bagi hasil (sesuai nisbah) pada akad mudharabahdan musyarakah. Solusi kedua yang ditawarkan yaitu dengan margin keuntungan, di mana margin keuntungan tersebut diterapkan untuk bebrerapa pembiayaan berdasar Natural Certainty Contracts (NCC), yaitu akad bisnis dengan memperolah kepastian pembayaran, baik berupa jumlahnya (amount) maupun waktuv(timing), contohnya pada pembiayaan salam, ijarah, murabahah, , dan istishna ${ }^{14}$.

Dalam konsep ekonomi Islam uang diposisikan sebagai barang milik masyarakat (public goods). Maka seseorang yang dengan sengaja menimbun uang atau membiarkan uang tidak produktif maka dapat menyebabkan berukurangnya jumlah uang beredar sehingga menghambat jalannya perekonomian. Apabila ada seseorang dengan sengaja menimbun uangnya dan tidak dibelanjakan, itu berarti dapat menghambat lancarnya

14 Yuliono, "Time Value of Moneydalam Perspektif Ekonomi Islam" El Jizya (Jurnal Ekonomi Islam) Vol 5. No 1, (2017) proses jual beli. Penumpukan uang mampu mendakatkan manusia kepada sifat tidak baik seperti rakus, tamak, malas, malas beramal.Oleh karena itu Islam melarang penimbunan uang (harta), memonopoli uang (harta), sebagaimana dijelaskan dalam al-Quran dalam surat AtTaubah 34.

al-Taubah 34

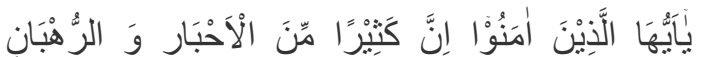

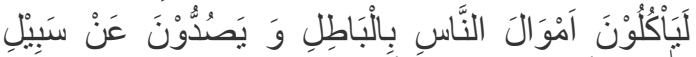

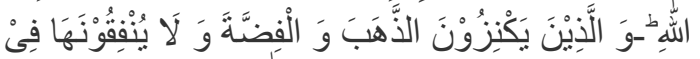

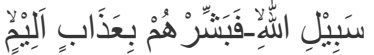

"Hai orang-orang yang beriman, Sesungguhnya sebahagian besar dari orang-orang alim Yahudi dan rahibrahib Nasrani benar-benar memakan harta orang dengan jalan batil dan mereka menghalang-halangi (manusia) dari jalan Allah. dan orang-orang yang menyimpan emas dan perak dan tidak menafkahkannya pada jalan Allah, Maka beritahukanlah kepada mereka, (bahwa mereka akan mendapat) siksa yang pedih."

Dalam ekonomi Islam uang yang ditimbun dan tidak produktif tidak akan bertambah bahkan semakin berkurang karena adanya kewajiban zakat bagi umat Islam, oleh karena itu uang harus berputar. Islam menganjurkan kita untuk melakukan bisnis (perdagangan), dan investasi di sektor riil. Uang yang berputar di sektor riil mampu memberikan peningkatan pendapatan bagi masyarakat umum yang berimbas 
pada meningkatnya daya beli masyarakat terhadap suatu komoditas.

\section{PENUTUP}

\section{Ekonomi Islam hanya} memandang uang sebagai alat tukar, bukan sebagai capital, atau barang dagangan (komoditas) jadi uang tidak dapat diperjual belikan dan dispekulasikan secara bebas. Uang itu sendiri tidak mampu memberi nilai guna. Namun fungsi uang tersebut yang mampu memberi kegunaan.

Dalam konsep ekonomi dikenal dengan nilai waktu uang yang menyebutkan bahwa nilai uang sekarang mempunyai nilai lebih dibandingkan dengan di masa yang akan datang. maka, uang haruslah bertambah dan bertumbuh karena adanya pertambahan waktu agar tidak tergerus nilainya untuk mengkorelasikan antara waktu dan nilai uang. Hal tersebut tidak terlepas dari implementasi dari sistem bunga (interest) atau riba.

Dalam konsep Islam persoalan riba berkaitan dengan masalah uang. Islam menegaskan dalam al-Qur'an yang menganggap haram bunga uang yang sama dengan riba. Ekomoni Islam tidak mengenal nilai waktu uang atau time value of money namun teori economic value of time lah yang dianggap benar dari pandangan ekonomi Islam. Artinya uang itu sendiri sebenarnya tidak memiliki nilai waktu. Namun waktulah yang memiliki nilai ekonomis.

\section{DAFTAR PUSTAKA}

Adiwarman A Karim, Ekonomi Makro Islami, Jakarta:PT.Rajagrafindo Persada. 2010

Agus Sartono, Manajemen Keuangan, Yogyakarta: BPFE, 1997. Andri Soemitra, Bank dan Lembaga Keuangan Syariah, Jakarta:Kencana, 2009.

Departemen Agama, Alquran dan Terjemahnya .Semarang: Asy-Syifa, 2000

Emily Nur Saidy, "Uang Dalam Tinjauan Ekonomi Islam" LAA MAISYIR, Volume 6, Nomor 2, (2017)

Iggi H. Achsien, Investasi Syariah di Pasar Modal: Menggagas Konsep danPraktik Manajemen Portofolio Syariah .Jakarta: Gramedia Pustaka Utama, 2003.

Huda, Bakhrul. "Etika Pertukaran Valas Dalam Pasar Valuta Asing Perspektif Fikih Sarf" dalam Iqtishadia Jurnal Ekonomi dan Perbankan Syariah Vol. 5 No. 1 (Juni 2018)

I Made Sudana, Manajemen Keuangan, Jakarta, Airlangga, 2017.

Kasmir, Bank dan lembaga keuangan lainnya.ed.revisi, Jakarta : Rajawali Pers.2008.

M.Nur Rianto Al Arif, Teori Makroekonomi Islam : Konsep,Teori, dan Analisis,Bandung, Alfabeta,2010.

M. Quraish Shihab, Tafsir al-Misbah, 15, Cet. 5 .Jakarta: Lentera Hati, 2012 
Rahmat Ilyas: "Time Value of Money dalam Perspektif Hukum Islam" AL'ADALAH Vol. 14, Nomor 1 (2017)

Yuliono, "Time Value Of Moneydalam Perspektif Ekonomi Islam” El Jizya (Jurnal Ekonomi Islam) Vol 5. No 1, (2017) 